\title{
Changes in Köppen-Geiger climate types under a future climate for Australia: hydrological implications
}

\author{
R. S. Crosbie ${ }^{1}$, D. W. Pollock ${ }^{2, *}$, F. S. Mpelasoka ${ }^{3}$, O. V. Barron ${ }^{2}$, S. P. Charles ${ }^{2}$, and M. J. Donn ${ }^{2}$ \\ ${ }^{1}$ CSIRO Water for a Healthy Country National Research Flagship, CSIRO Land and Water, PMB 2, \\ Glen Osmond SA 5064, Australia \\ ${ }^{2}$ CSIRO Water for a Healthy Country National Research Flagship, CSIRO Land and Water, Private Bag 5, Wembley, \\ WA 6913, Australia \\ ${ }^{3}$ CSIRO Water for a Healthy Country National Research Flagship, CSIRO Land and Water, G.P.O. Box 1666, \\ Canberra ACT 2601, Australia \\ *now at: Rio Tinto Iron Ore, 152-158 St George's Terrace Perth 6000, Western Australia
}

Correspondence to: R. S. Crosbie (russell.crosbie@csiro.au)

Received: 17 May 2012 - Published in Hydrol. Earth Syst. Sci. Discuss.: 12 June 2012

Revised: 29 August 2012 - Accepted: 29 August 2012 - Published: 18 September 2012

\begin{abstract}
The Köppen-Geiger climate classification has been used for over a century to delineate climate types across the globe. As it was developed to mimic the distribution of vegetation, it may provide a useful surrogate for making projections of the future distribution of vegetation, and hence resultant hydrological implications, under climate change scenarios. This paper developed projections of the KöppenGeiger climate types covering the Australian continent for a 2030 and 2050 climate relative to a 1990 historical baseline climate using 17 Global Climate Models (GCMs) and five global warming scenarios. At the highest level of classification for $\mathrm{a}+2.4{ }^{\circ} \mathrm{C}$ future climate (the upper limit projected for 2050) relative to the historical baseline, it was projected that the area of the continent covered by

- tropical climate types would increase from $8.8 \%$ to $9.1 \%$;

- arid climate types would increase from $76.5 \%$ to $81.7 \%$;

- temperate climate types would decrease from $14.7 \%$ to $9.2 \%$;

- cold climate types would decrease from $0.016 \%$ to $0.001 \%$.
\end{abstract}

Previous climate change impact studies on water resources in Australia have assumed a static vegetation distribution.
If the change in projected climate types is used as a surrogate for a change in vegetation, then the major transition in climate from temperate to arid in parts of Australia under a drier future climate could cause indirect effects on water resources. A transition from annual cropping to perennial grassland would have a compounding effect on the projected reduction in recharge. In contrast, a transition from forest to grassland would have a mitigating effect on the projected reduction in runoff.

\section{Introduction}

The Köppen-Geiger climate classification (Köppen, 1936) is the most widely applied method for determining climate zones; it has been used recently in such diverse fields as environmental science, veterinary science and mathematics (Rubel and Kottek, 2011). Its origins can be traced to observations of the distribution of vegetation throughout Russia (Köppen, 1884) and is still under active development (Kottek et al., 2006; Peel et al., 2007; Rubel and Kottek, 2010).

The central theme of the Köppen-Geiger climate classification is that climate controls the distribution of vegetation (Köppen, 1884), as reflected in some of the names given to the particular climate types, e.g. savannah, steppe and tundra (Köppen, 1936). This idea has been used repeatedly over the years such as for Budyko's (1974) geobotanic zones and the 
global biome model of Prentice et al. (1992). This link between climate and vegetation is very useful because climate is more readily mapped than vegetation.

Vegetation also exerts a strong control over hydrology. Using data from over 250 catchments around the world, Zhang et al. (2001) demonstrated that for any given annual average rainfall a forested catchment will have a higher evapotranspiration than a grassed catchment. Similarly, from a review of Australian field studies of groundwater recharge, Crosbie et al. (2010a) showed that for a given annual average rainfall groundwater recharge was highest under annual vegetation and lowest under tree type vegetation. Any change in vegetation will have a corresponding impact upon the hydrology of a catchment.

Projections of water resources availability under a future climate have generally assumed a static vegetation coverage, either implicitly through calibration of a rainfall-runoff model (Chiew et al., 2009b) or explicitly through having a pre-defined vegetation layer as an input to the modelling process (Crosbie et al., 2010b). The limitations of this assumption have been discussed (Holman et al., 2012; Holman, 2006), but there are few examples in the literature of the indirect effects of climate change on water resources due to vegetation change (one such example is Holman, 2006). Projections of changes in vegetation can be modelled in managed systems using coupled crop growth and economic models (Holman, 2006) or in natural systems using dynamic vegetation growth models (Cramer et al., 2001), however this adds complexity and computational demands upon studies investigating the climate change impacts on water resources.

Given that the Köppen-Geiger climate classification was developed to mimic the distribution of vegetation types (Köppen, 1884), it may provide a relatively simple surrogate for providing projections of future vegetation types under climate change scenarios (Kleidon et al., 2000). This paper aims to investigate the changes in climate types for Australia under a future climate based upon projections from an ensemble of global climate models (GCMs) and a range of global warming scenarios and then to discuss the hydrological implications of the projected change in climate types.

\section{Methods}

The Köppen-Geiger classification is calculated from long term averages of temperature and precipitation at an annual, seasonal and monthly time scale. For the definitions described by Peel et al. (2007), there are 30 discrete climate types, 15 of which are present in Australia (Table 1). At the highest level there are five climate types: tropical (A), arid (B), temperate (C), cold (D) and polar (E). Within these five top level climate types there are a number of further classes with a second level and third level delineated by metrics derived from monthly rainfall and temperature. For a full description of the classification criteria, the reader is referred to Peel et al. (2007).
For this study, the historical climate data used as inputs for calculating the distribution of the Köppen-Geiger climate types across Australia came from the monthly gridded $\left(0.05^{\circ}\right)$ climate surfaces of the Bureau of Meteorology (Jones et al., 2009). These are created by interpolation of rainfall and temperature anomalies from observation data relative to the period 1971-2000, for the year 1990 this included over 6000 rainfall stations and 600 temperature stations (Jones et al., 2009).

The historical time period considered by this study is 1970 to 2010 , this is 20 years either side of a 1990 centred baseline climate. The future climate scenarios are defined by global warming above a 1990 climate. We have considered a low, medium and high global warming scenario for 2030 $\left(+0.7^{\circ} \mathrm{C},+1.0^{\circ} \mathrm{C}\right.$ and $\left.+1.3{ }^{\circ} \mathrm{C}\right)$ and $2050\left(+1.0^{\circ} \mathrm{C},+1.7^{\circ} \mathrm{C}\right.$ and $+2.4^{\circ} \mathrm{C}$ ) based upon previous work (Crosbie et al., 2012; Post et al., 2012) that inferred the degree of global warming from the IPCC Fourth Assessment Report (IPCC, 2007; Nakicenovic and Swart, 2000). These levels of global warming can be considered a surrogate for time, in that the $+2.4^{\circ} \mathrm{C}$ used here as the high global warming scenario for 2050 could equally be considered a very low global warming scenario for 2100.

For the future climate scenarios the outputs of the GCMs had to be downscaled from the coarse grid of the GCMs $\left(>1^{\circ}\right)$ to the fine grid of the historical climate data $\left(0.05^{\circ}\right)$, downscaling is also necessary to remove the bias from the GCM data (Fowler et al., 2007). The future climate output from 17 GCMs (Table 2) that are archived by the World Climate Research Programme's (WCRP's) Coupled Model Intercomparison Project phase 3 (CMIP3) multi-model dataset (Meehl et al., 2007) were used to derive monthly scaling factors as a percentage change in rainfall per degree of global warming and a change in temperature per degree of global warming at the grid resultion of each GCM (Mitchell, 2003; Mpelasoka and Chiew, 2009; Suppiah et al., 2007). These scaling factors were applied to the observed time series of historical monthly gridded rainfall and temperature to create projections for the five global warming scenarios (the $+1.0^{\circ} \mathrm{C}$ is used for both 2030 and 2050) for each of the 17 GCMs. These 85 future climate variants were then assessed on a gridded basis to determine the projected future distribution of Köppen-Geiger climate types across Australia using the definitions of Peel et al. (2007). To simplify the results, the mode of the Köppen-Geiger climate types derived from the $17 \mathrm{GCMs}$ has been reported for each of the five global warming scenarios.

The method used here is different to Rubel and Kottek (2010) who calculated climate types for four emission scenarios after taking the average rainfall and temperature from an ensemble of five GCMs. The advantage of the method described here is the ability to examine projected climate type differences between GCMs, thus allowing a more thorough investigation of the sources of uncertainty in projected climate types. 
Table 1. Description of the Köppen-Geiger climate types in Australia, see Peel et al. (2007) for classification criteria.

\begin{tabular}{ll}
\hline Code & Description \\
\hline Af & Tropical, Rainforest \\
Am & Tropical, Monsoon \\
Aw & Tropical, Savannah \\
BWh & Arid, Desert, Hot \\
BWk & Arid, Desert, Cold \\
BSh & Arid, Steppe, Hot \\
BSk & Arid, Steppe, Cold \\
Csa & Temperate, Dry Summer, Hot Summer \\
Csb & Temperate, Dry Summer, Warm Summer \\
Cwa & Temperate, Dry Winter, Hot Summer \\
Cfa & Temperate, Without dry season, Hot Summer \\
Cfb & Temperate, Without dry season, Warm Summer \\
Cfc & Temperate, Without dry season, Cold Summer \\
Dfb & Cold, Without dry season, Warm Summer \\
Dfc & Cold, Without dry season, Cold Summer \\
\hline
\end{tabular}

\section{Results}

The historical baseline climate types derived from this study are different from those produced by Peel et al. (2007) and Kottek et al. (2006) due to differences in the input data. Jones et al. (2009) had access to more than three times as many rainfall stations and more than twice as many temperature stations compared to Peel et al. (2007) to create the gridded climate surfaces used here, and the resolution of the interpolation is also higher from Jones et al. (2009) compared to that used by Peel et al. (2007) or Kottek et al. (2006). Jones et al. (2009) also used an interpolation algorithm that included elevation and so the major differences in climate types are in the higher elevation areas of Victoria (Vic), Tasmania (Tas) and New South Wales (NSW) where the climate types Cfc, $\mathrm{Dfb}$ and Dfc are present in this analysis but not that of Peel et al. (2007) or Kottek et al. (2006) (Fig. 1). Overall the difference is quite minor with the arid types (B) being dominant (76.5\% here compared to $77.8 \%$ in Peel et al., 2007), followed by the temperate (C) (14.7\% cf. $13.9 \%)$, tropical (A) $(8.8 \%$ cf. $8.3 \%)$ and cold (D) $(0.016 \%$ here, not present in Peel et al., 2007, or Kottek et al., 2006).

The 17 GCMs used here all give different distributions of future climate types (Fig. 2). The variability in projections of climate types is consistent with the variability previously reported in rainfall (Chiew et al., 2009a), runoff (Chiew et al., 2009b) and recharge (Crosbie et al., 2010b). The most variability between GCMs is seen in the tropical (A) climate types where the proportion of the continent with these climate types is projected to decrease by 8 GCMs and increase by 9 GCMs (Fig. 3), this inconsistency between GCMs across northern Australia has been reported previously (CSIRO, 2009a). There is more consensus amongst the projected arid (B) climate types where 15 out of 17 GCMs

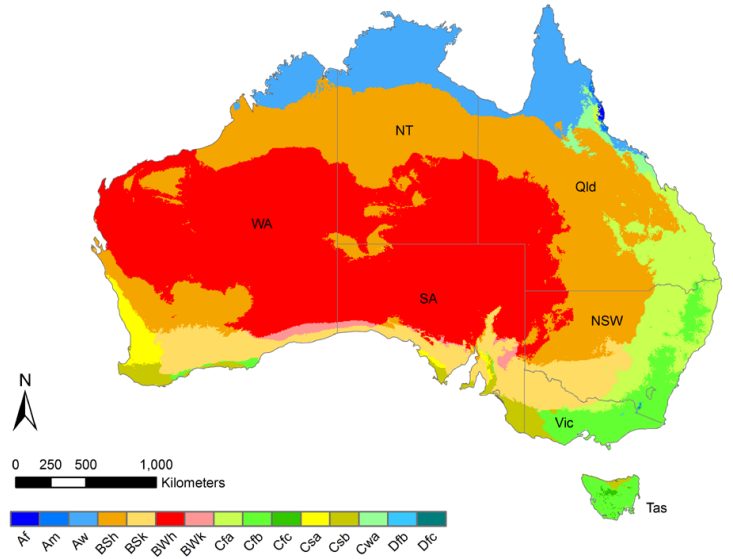

Fig. 1. Historical baseline Köppen-Geiger climate types for the period 1970-2010.

project an increase in their proportion of the continent. The projections derived from all GCMs agree that the proportion of the continent covered by the temperate (C) and cold (D) climate types will decrease. The variability across GCMs increases as the degree of global warming increases, highlighting the uncertainty in projecting future climate types, the exception is for the cold (D) climate types where the proportion of the continent is approaching zero with increasing global warming.

The mode of the climate types from the ensemble of GCMs was determined for each global warming scenario at the historical grid cell scale (Fig. 4) and was further simplified to just the changes in top level classifications (Fig. 5). The tropical (A) climate types occur across the north of the continent and are expanding overall with increasing global warming, this is due to an expansion along the Queensland (Qld) coast (displacing temperate) that is progressing faster than the contraction inland (being replaced by arid). Overall the tropical (A) area is projected to expand from $8.8 \%$ of the continent under the historical baseline up to $9.1 \%$ for $+2.4^{\circ} \mathrm{C}$. The arid (B) climate types are expanding in every direction with increasing global warming; the area is projected to increase from $76.5 \%$ to $81.7 \%$ of the continent for $+2.4{ }^{\circ} \mathrm{C}$. The greatest area of expansion is in the southeast of Queensland, but the more surprising result is that by $+1.0^{\circ} \mathrm{C}$, the arid climate types have spread into southern Victoria. The temperate $(\mathrm{C})$ climate types are contracting to the south-west, south and south-east after being replaced by arid (B) climate types and also along the Queensland coast after being replaced by tropical (A) climate types. Overall the temperate climate types are projected to contract from $14.7 \%$ to $9.2 \%$ of the continent for $+2.4^{\circ} \mathrm{C}$. The cold (D) climate types only occupy a very small area $(0.016 \%)$ in the southeast of the continent under the historical baseline climate, this proportion is projected to rapidly disappear with increasing 


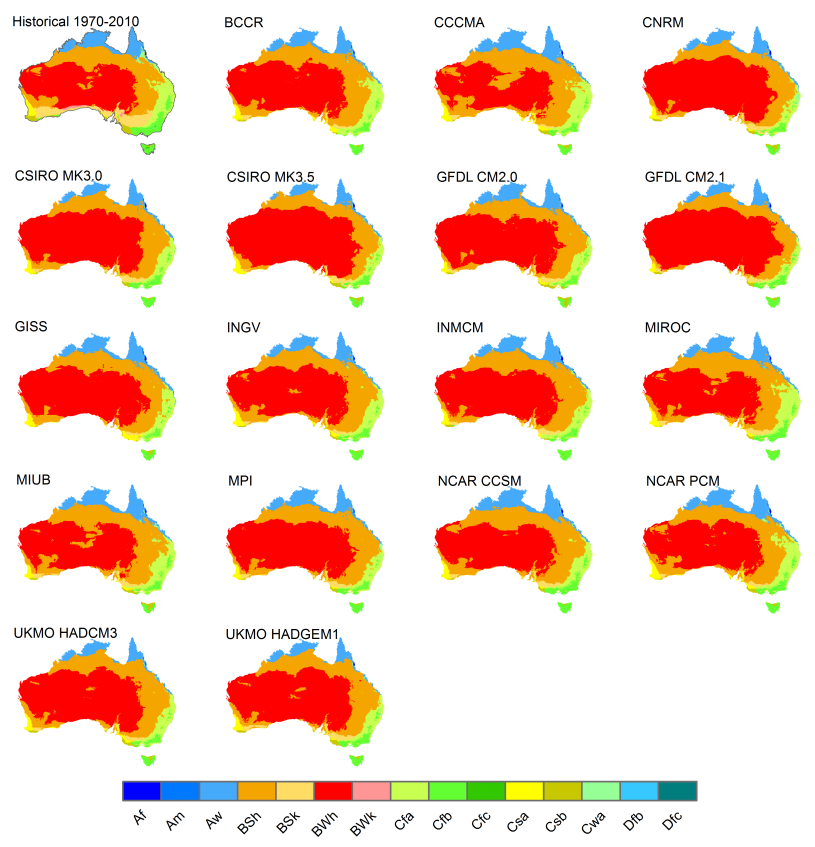

Fig. 2. Köppen-Geiger climate types under a future climate of $+2.4{ }^{\circ} \mathrm{C}$ derived from $17 \mathrm{GCMs}$ (historical baseline period is included for reference).

global warming to the point where there are only 2 grid cells $\left(\sim 50 \mathrm{~km}^{2}\right)$ remaining for $+2.4^{\circ} \mathrm{C}$.

A summary of the changes in the proportion of the continent of each climate type, at the third level of the classification, are shown in Fig. 6. For Af (tropical, Rainforest), the area increases to a peak at $+1.0^{\circ} \mathrm{C}$ before declining with further increases in global warming to be $3 \%$ above the historical baseline by $+2.4{ }^{\circ} \mathrm{C}$. The area of Am (tropical, Monsoon) increases with increasing global warming to be $50 \%$ above the historical baseline by $+2.4^{\circ} \mathrm{C}$. The total area of the Af and Am climate types are quite small $(0.04 \%$ and $0.08 \%$ respectively for the historical baseline), the majority of the tropical climate type is made up of Aw (tropical, Savannah; $8.7 \%$ historical baseline). This climate type is projected to have a small increase in area with increasing global warming ( $8.9 \%$ of the continent for $+2.4{ }^{\circ} \mathrm{C}$ ); this is caused by a contraction in inland areas and an expansion southward along the Queensland coast.

The arid climate types cover most of the continent, of them BWh (arid, Desert, Hot) covers the most area at $39.2 \%$ under the historical baseline (Fig. 6). This climate type is projected to expand to the south-west, south and south-east and by $+2.4{ }^{\circ} \mathrm{C}$ covers $49.4 \%$ of the continent. Under the historical baseline climate BSh (arid, Steppe, Hot) covers the second greatest area $(29.2 \%)$ and this is projected to increase to the north, east, south-east, south and south-west to a total of $31.1 \%$ of the continent by $+2.4{ }^{\circ} \mathrm{C}$. Under the historical baseline climate BSk (arid, Steppe, Hot) had the fourth greatest area $(7.4 \%)$ but is projected to see the majority $(83 \%)$ of this
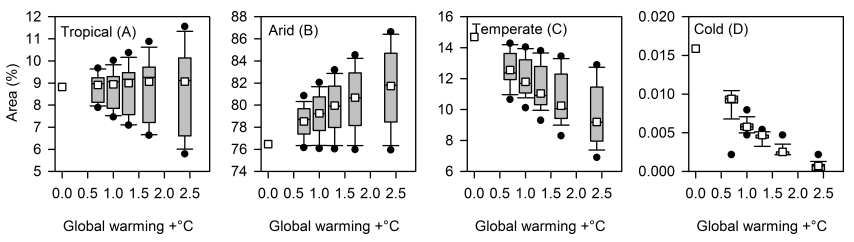

Fig. 3. Boxplots of the proportion of Australia covered by the top level Köppen-Geiger climate types under a future climate derived from $17 \mathrm{GCMs}$. The grey box represents the interquartile range, the line in the box is the median, the whiskers contain $95 \%$ of the data and the black circles are outliers. The white squares represent the mode as shown in Fig. 4. The baseline historical climate is represented in this figure by a global warming of $0^{\circ} \mathrm{C}$.

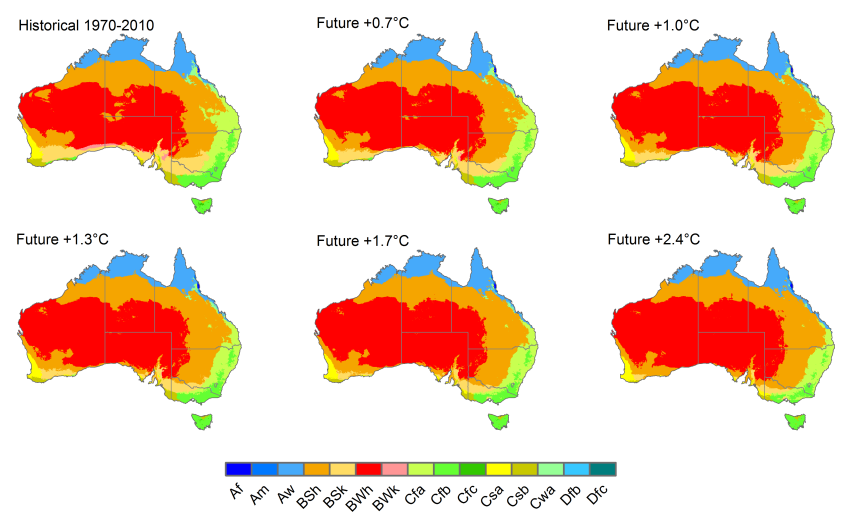

Fig. 4. Köppen-Geiger climate types for the mode of $17 \mathrm{GCMs}$ for 5 global warming scenarios (historical baseline period is included for reference).

area replaced by BSh by $+2.4{ }^{\circ} \mathrm{C}$. The BWk (arid, steppe, cold) climate type only occupies a small proportion of the continent under the historical baseline climate $(0.7 \%)$ and this is completely replaced by BWh by $+2.4^{\circ} \mathrm{C}$.

The temperate $(\mathrm{C})$ climate types are projected to have the greatest reduction in area under a future climate (Fig. 6). Climate type Csa (temperate, dry summer, hot summer) initially decreases in area with increasing global warming to reach a minimum at $+1.0^{\circ} \mathrm{C}$ where it is being replaced by $\mathrm{BSh}$, with further global warming Csa is displacing Csb (temperate, Dry Summer, Warm Summer) and by $+2.4^{\circ} \mathrm{C}$ occupies $1 \%$ more area than it did under the historical baseline climate (1.1\% of the continent). Climate type Csb occupied $1.6 \%$ of the continent under the historical baseline climate and this decreases rapidly with increasing global warming for a $70 \%$ reduction in area by $+2.4{ }^{\circ} \mathrm{C}$. The Cwa (temperate, Dry Winter, Hot Summer) climate type only occupies a small area ( $0.7 \%$ of the continent) of north Queensland under the historical baseline climate. Under the future climate scenarios this area is projected to be displaced by Aw and by $+2.4{ }^{\circ} \mathrm{C}$ the area is projected to be reduced by $92 \%$. Under the historical baseline climate, Cfa (temperate, Without Dry Season, Hot Summer) occupies the largest area of all the temperate 
Table 2. List of GCMs used in this study also showing the abbreviations used in Fig. 2.

\begin{tabular}{|c|c|c|c|}
\hline Organisation & Country & CMIP3 I.D. & Abbrev. \\
\hline Bjerknes Centre for Climate Research & Norway & BCCR-BCM2.0 & BCCR \\
\hline Canadian Centre for Climate Modelling \& Analysis & Canada & CGCM3.1(T63) & CCCMA \\
\hline Météo-France/Centre National de Recherches Météorologiques & France & CNRM-CM3 & CNRM \\
\hline CSIRO Atmospheric Research & Australia & CSIRO-Mk3.0 & CSIRO MK3.0 \\
\hline CSIRO Atmospheric Research & Australia & CSIRO-Mk3.5 & CSIRO MK3.5 \\
\hline US Dept. of Commerce/NOAA/Geophysical Fluid Dynamics Laboratory & USA & GFDL-CM2.0 & GFDL CM2.0 \\
\hline US Dept. of Commerce/NOAA/Geophysical Fluid Dynamics Laboratory & USA & GFDL-CM2.1 & GFDL CM2.1 \\
\hline NASA/Goddard Institute for Space Studies & USA & GISS-ER & GISS \\
\hline Instituto Nazionale di Geofisica e Vulcanologia & Italy & INGV-SXG & INGV \\
\hline Institute for Numerical Mathematics & Russia & INM-CM3.0 & INMCM \\
\hline $\begin{array}{l}\text { Center for Climate System Research (The University of Tokyo), National } \\
\text { Institute for Environmental Studies, and Frontier Research Center for } \\
\text { Global Change (JAMSTEC) }\end{array}$ & Japan & MIROC3.2 (medres) & MIROC \\
\hline $\begin{array}{l}\text { Meteorological Institute of the University of Bonn, Meteorological } \\
\text { Research Institute of KMA, and Model and Data group }\end{array}$ & Germany/Korea & ECHO-G & MIUB \\
\hline Max Planck Institute for Meteorology & Germany & ECHAM5/MPI-OM & MPI \\
\hline National Center for Atmospheric Research & USA & CCSM3 & NCAR CCSM \\
\hline National Center for Atmospheric Research & USA & PCM & NCAR PCM \\
\hline Hadley Centre for Climate Prediction and Research/Met Office & UK & UKMO-HadCM3 & UKMO HADCM3 \\
\hline Hadley Centre for Climate Prediction and Research/Met Office & UK & UKMO-HadGEM1 & UKMO HADGEM 1 \\
\hline
\end{tabular}
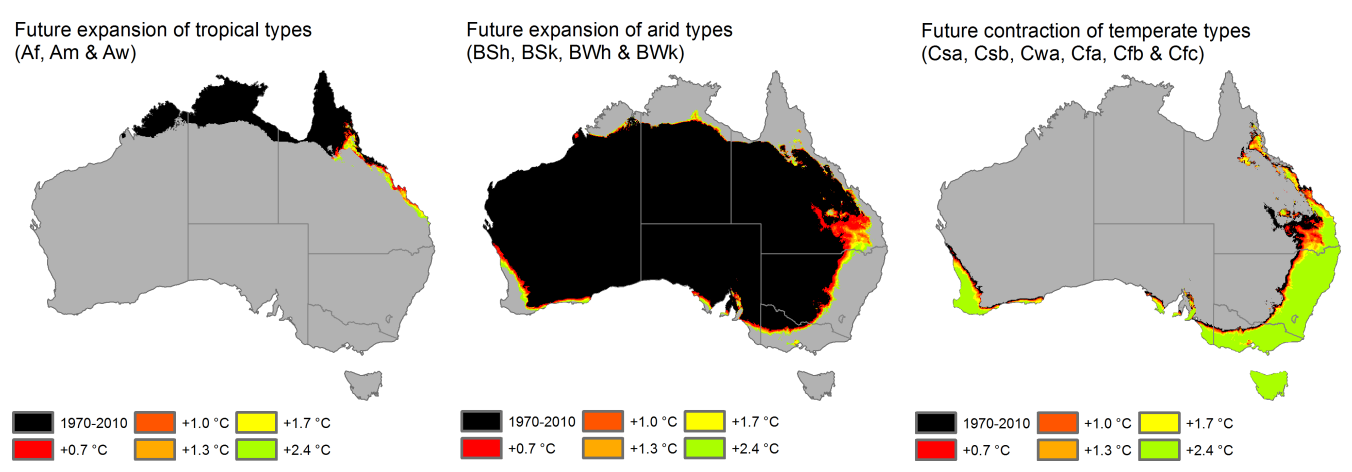

Fig. 5. Future extents of the top level Köppen-Geiger classification - arid, tropical and temperate (cold not shown on this plot).

climate types ( $6.5 \%$ of the continent). Under the future climate scenarios this climate type is moving to the south-east, it is being replaced by BSh from the north-west and is replacing $\mathrm{Cfb}$ (temperate, Without Dry Season, Warm Summer) to the south-east, overall the area it occupies is projected to decrease by $24 \%$ by $+2.4{ }^{\circ} \mathrm{C}$. Under the future climate scenarios, the $\mathrm{Cfb}$ climate type is decreasing in area with increasing global warming, by $+2.4{ }^{\circ} \mathrm{C}$ it is projected to have lost $44 \%$ of the $4.6 \%$ of the continent that it occupied under the historical baseline climate. The Cfc (temperate, without dry season, cold summer) climate type only occurs in small areas $(0.07 \%$ of the continent) of Tasmania (Tas) under this historical baseline climate, under the future climate scenarios it is projected to be increasingly replaced by $\mathrm{Cfb}$ with increased global warming $\left(94 \%\right.$ reduction by $\left.+2.4{ }^{\circ} \mathrm{C}\right)$.

The cold (D) climate types Dfb (cold, without dry season, warm summer) and Dfc (cold, without dry season, cold summer) only occupy a small area $(0.01 \%$ and $0.006 \%$ respectively) of New South Wales and Victoria at high altitude under the historical baseline climate. After $+1.0^{\circ} \mathrm{C}$ Dfc is projected to be completely replaced (by $\mathrm{Cfb}$ ) and by $+2.4^{\circ} \mathrm{C}$ the projected area of Dfb is reduced by $93 \%$.

\section{Discussion}

As pointed out by Cannon (2012), at the highest level of the Köppen-Geiger classification it is only the arid (B) class that is discriminated by rainfall, this means that transitions in climate types due to climate change may not be sensitive to changes in rainfall. For this paper, which is focused on Australia, this is not a big problem as the major transitions projected in climate type involve the arid (B) climate types.

The modelled direct effects of projected climate change on water resources have been extensively studied in Australia in recent years (CSIRO, 2008, 2009a, c, b). The results of these studies can be placed into the context of the Köppen-Geiger 

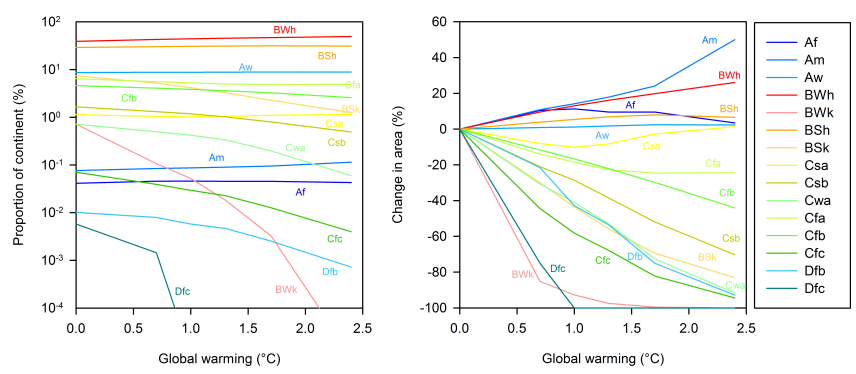

Fig. 6. The proportion of Australia covered by the Köppen-Geiger climate types for 5 global warming scenarios and the mode of 17 GCMs and the change in area relative to the historical baseline scenario.

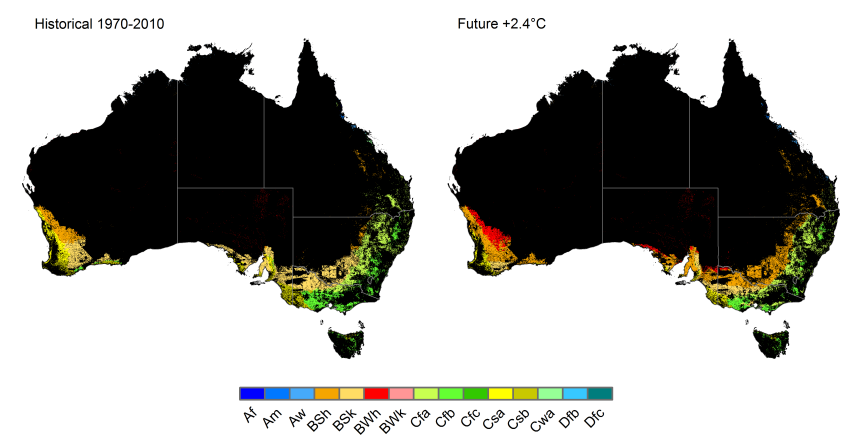

Fig. 7. Distribution of Köppen-Geiger climate types under the present extent of annual crops and pastures (BRS, 2008) (blacked out areas of the figure do not have annual vegetation).

climate classification. In the historical baseline climate, the cold (D) climate types form a subset of the extremely high yield zone of Donohue et al. (2011) that is defined as energy limited and are responsible for a disproportionately large amount of the runoff in the Murray-Darling Basin (MDB). The change in climate type from cold (D) to temperate (C) is the result of a projected increase in temperature and therefore potential evapotranspiration, combined with a projected decrease in rainfall (Chiew et al., 2009a) and the area that is energy limited is reduced resulting in less runoff. The area classified as cold (D) under the historical baseline climate is projected to be amongst the areas with the greatest reduction in runoff in the MDB (Chiew et al., 2009b).

The transition of areas from temperate (C) to arid (B) climate types could cause either an increase or decrease in recharge. Barron et al. (2012) showed that groundwater recharge under BSh is higher for a given annual rainfall than Cfa but BSh by definition experiences a lower rainfall than $\mathrm{Cfa}$ (Peel et al., 2007). The majority of the areas projected to transition from temperate (C) to arid (B) under a future climate are also projected to have a reduction in recharge (Crosbie et al., 2012), the analysis of Barron et al. (2012) suggests that the reduction in recharge would have been greater without the change in climate type.
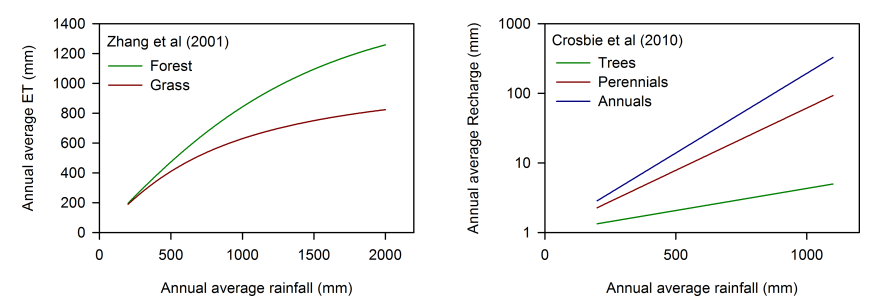

Fig. 8. Comparison of the evapotranspiration and recharge for different vegetation derived from observed field data. The evapotranspiration curves are derived from Fig. 9 in Zhang et al. (2001) and the recharge curves are derived from Fig. 6 in Crosbie et al. (2010a).

For a future climate of $+2.4{ }^{\circ} \mathrm{C}, 24 \%$ of the country is projected to change climate type. This includes the disappearance of two climate types completely (BWk and Dfc) and five others that are projected to occupy less than one third of the area that they occupied under the historical baseline climate (BSk, Csb, Cwa, Cfc and Dfb). These changes in climate type will cause changes in vegetation types that are not actively managed and potentially also a loss of biodiversity (Markham, 1996). Dynamic vegetation growth models have been used to assess the temporal (as well as spatial) scale of potential vegetation changes and in some cases it has been reported that vegetation change could take over $100 \mathrm{yr}$ to come to equilibrium after the climate has reached a new equilibrium (Cramer et al., 2001; Loehle, 2011). There are also observations that suggest that vegetation change could occur much more rapidly, this could occur due to a catastrophic event such as forest mortality (Mitchell et al., 2012) or gradually over a couple of decades as has been observed through an increase in persistent vegetation (Donohue et al., 2009).

In actively managed agricultural landscapes, any change in vegetation type will result from socio-economic factors rather than climate change alone (Holman, 2006). This will occur when it is no longer profitable to grow crops. Under the historical baseline climate only the northern wheatbelt (WA) has a significant area of annual vegetation in the BSh climate type (Fig. 7). The northern wheatbelt is currently amongst the lowest yielding grain growing areas in the country (Kokic et al., 2005). The majority of annual cropping is undertaken in temperate (C) or BSk climate types, and under the current distribution of cropping zones there is nowhere in Australia where there is annual vegetation under the $\mathrm{BWh}$ climate type. Under a $+2.4{ }^{\circ} \mathrm{C}$ future climate BWh has moved into the northern wheatbelt (WA), far west, mid north, riverland (SA) and the sunraysia (Vic) areas of annual vegetation. The BSh climate type is projected to be dominant in the southern wheatbelt (WA), Eyre Peninsula, Yorke Peninsula, Mallee (SA), northern plains (Vic), the northern, central and southern slopes (NSW), and the Darling Downs (Qld). Large reductions in wheat yield have been projected under a future climate in the areas that are projected to become BWh 
climate types (Farre and Foster, 2010; Wang et al., 2009; Luo et al., 2005).

If areas that are currently under annual crops and pastures change to another land use due to climate change, then there will be a corresponding hydrological impact. For example, the northern wheatbelt (WA) is projected to have a 10-20\% reduction in recharge for a median 2050 climate assuming that the vegetation type remains static (Crosbie et al., 2012). However, if the vegetation were to revert to a more naturalised state of perennial vegetation then the recharge could be reduced by at least double the amount projected for climate change directly (Fig. 8). In this example the direct and indirect effects of climate change upon groundwater recharge are compounded (i.e. a positive feedback).

The largest transition in climate types projected for $+2.4^{\circ} \mathrm{C}$ is from temperate (C) to arid (B); this could cause a transition in vegetation type in some areas from forest to grassland. Many of the forested areas of south-east Australia are projected to have a decrease in runoff due to reduced rainfall under a future climate (Chiew et al., 2009b). Some of these areas are also projected to have a change in climate type from temperate (C) to arid (B). Zhang et al. (2001) showed that for a given annual rainfall, forests have greater evapotranspiration than grassland and consequently less runoff (Fig. 8). If reduced rainfall under a future climate results in a transition from forest to grassland, then the effects of reduced rainfall upon runoff could be mitigated by a reduction in evapotranspiration from the vegetation change (i.e. a negative feedback).

\section{Conclusions}

This paper has presented projections of Köppen-Geiger climate types across Australia for future climates based upon 17 GCMs and five global warming scenarios. There is no consensus amongst the GCMs in the projections for the Tropics (A), where nine GCMs project an increase in area and eight project a decrease. The mode of the GCMs shows an increase of $0.3 \%$ in area for a global warming scenario of $+2.4^{\circ} \mathrm{C}$ to $9.1 \%$ from $8.8 \%$ under the historical baseline climate. For the arid (B) climate types 15 out of $17 \mathrm{GCMs}$ project an increase in area with a mode of $81.7 \%$ of the continent for $+2.4{ }^{\circ} \mathrm{C}$ compared to $76.5 \%$ under the historical baseline climate. All 17 GCMs project reductions in the temperate (C) and cold (D) climate types. The increase in the area covered by the arid (B) climate types is balanced by a reduction in the temperate $(\mathrm{C})$ climate types with the historical baseline climate being $14.7 \%$ of the continent and this is projected to reduce to $9.2 \%$ for a $+2.4{ }^{\circ} \mathrm{C}$ future climate. The cold (D) climate types only occupy a very small part of the continent under the historical baseline climate $(0.016 \%)$ and this is reduced by $95 \%$ under $\mathrm{a}+2.4{ }^{\circ} \mathrm{C}$ future climate.

Under a warmer drier climate, previous studies have made projections for reductions in runoff and recharge over large parts of Australia assuming static vegetation coverage. As the Köppen-Geiger climate classification was developed based upon the distribution of vegetation it may provide a useful surrogate for vegetation change projections under a future climate. If vegetation change were to be incorporated into future projections of water resources availability it could provide different results. A transition in vegetation type from annual cropping to perennial grassland would have a compounding effect on a reduction in recharge, whereas a transition from forest vegetation to grassland would have a mitigating effect upon a reduction in runoff. Therefore, it is recommended that detailed research is necessary to incorporate the indirect effects of climate change due to vegetation change into studies of climate change impacts upon water resources in Australia.

Acknowledgements. The authors would like to acknowledge the National Water Commission for providing funding to support the Climate Change Impacts on Groundwater Resources project under the National Groundwater Action Plan and CMIP3 for providing GCM outputs.

Edited by: Y. Fan

\section{References}

Barron, O. V., Crosbie, R. S., Pollock, D., Dawes, W. R., Charles, S. P., Pickett, T., and Donn, M.: Climatic controls on diffuse groundwater recharge across Australia, Hydrol. Earth Syst. Sci. Discuss., 9, 6023-6062, doi:10.5194/hessd-9-6023-2012, 2012.

BRS: Integrated Vegetation Cover 2008, Bureau of Rural Sciences, Canberra, 2008.

Budyko, M. I.: Climate and Life, International Geophysics, Academic Press, 508 pp., 1974.

Cannon, A. J.: Köppen versus the computer: comparing KöppenGeiger and multivariate regression tree climate classifications in terms of climate homogeneity, Hydrol. Earth Syst. Sci., 16, 217229, doi:10.5194/hess-16-217-2012, 2012.

Chiew, F. H. S., Teng, J., Vaze, J., and Kirono, D. G. C.: Influence of global climate model selection on runoff impact assessment, J. Hydrol., 379, 172-180, 2009a.

Chiew, F. H. S., Teng, J., Vaze, J., Post, D. A., Perraud, J. M., Kirono, D. G. C., and Viney, N. R.: Estimating climate change impact on runoff across southeast Australia: Method, results, and implications of the modeling method, Water Resour. Res., 45, W10414, doi:10.1029/2008WR007338, 2009b.

Cramer, W., Bondeau, A., Woodward, F. I., Prentice, I. C., Betts, R. A., Brovkin, V., Cox, P. M., Fisher, V., Foley, J. A., Friend, A. D., Kucharik, C., Lomas, M. R., Ramankutty, N., Sitch, S., Smith, B., White, A., and Young-Molling, C.: Global response of terrestrial ecosystem structure and function to $\mathrm{CO}_{2}$ and climate change: results from six dynamic global vegetation models, Glob. Change Biol., 7, 357-373, doi:10.1046/j.13652486.2001.00383.x, 2001.

Crosbie, R. S., Jolly, I. D., Leaney, F. W., and Petheram, C.: Can the dataset of field based recharge estimates in Australia be used to 
predict recharge in data-poor areas?, Hydrol. Earth Syst. Sci., 14, 2023-2038, doi:10.5194/hess-14-2023-2010, 2010a.

Crosbie, R. S., McCallum, J. L., Walker, G. R., and Chiew, F. H. S.: Modelling the climate change impact on groundwater recharge in the Murray-Darling Basin, Hydrogeol. J., 18, 1639-1656, 2010 b.

Crosbie, R. S., Pickett, T., Mpelasoka, F. S., Hodgson, G., Charles, S. P., and Barron, O. V.: An assessment of the climate change impacts on groundwater recharge at a continental scale using a probabilistic approach with an ensemble of GCMs, Climatic Change, online first: doi:10.1007/s10584-012-0558-6, 2012.

CSIRO: Water availability in the Murray-Darling Basin. A report to the Australian Government from the CSIRO Murray-Darling Basin Sustainable Yields Project, CSIRO: Water for a Healthy Country National Research Flagship, Australia, 67 pp., 2008.

CSIRO: Water in northern Australia: Summary of reports to the Australian Government from the CSIRO Northern Australia Sustainable Yields Project, CSIRO: Water for a Healthy Country National Research Flagship, Canberra, 2009a.

CSIRO: Water yields and demands in south-west Western Australia: Summary of a report to the Australian Government from the CSIRO SWSY Project, CSIRO: Water for a Healthy Country National Research Flagship, 2009b.

CSIRO: Water availability for Tasmania: CSIRO Tasmania Sustainable Yields Project, CSIRO: Water for a Healthy Country National Research Flagship, Canberra, 2009c.

Donohue, R. J., McVicar, T. R., and Roderick, M. L.: Climaterelated trends in Australian vegetation cover as inferred from satellite observations, 1981-2006, Glob. Change Biol., 15, 10251039, 2009.

Donohue, R. J., Roderick, M. L., and McVicar, T. R.: Assessing the differences in sensitivities of runoff to changes in climatic conditions across a large basin, J. Hydrol., 406, 234-244, doi:10.1016/j.jhydrol.2011.07.003, 2011.

Farre, I. and Foster, I.: Impact of climate change on wheat yields in Western Australia. Will wheat production be more risky in the future?, Food Security from Sustainable Agriculture, Proceedings of 15th Agronomy Conference, Lincoln, New Zealand, 2010.

Fowler, H. J., Blenkinsop, S., and Tebaldi, C.: Linking climate change modelling to impacts studies: recent advances in downscaling techniques for hydrological modelling, Int. J. Climatol., 27, 1547-1578, doi:10.1002/joc.1556, 2007.

Holman, I. P.: Climate change impacts on groundwater recharge: uncertainty, shortcomings and the way forward?, Hydrogeol. J., 14, 637-647, 2006.

Holman, I. P., Allen, D. M., Cuthbert, M. O., and Goderniaux, P.: Towards best practice for assessing the impacts of climate change on groundwater, Hydrogeol. J., 20, 1-4, doi:10.1007/s10040011-0805-3, 2012.

IPCC: Climate Change 2007: The Physical Science Basis. Contribution of Working Group 1 to the Fourth Assessment Report of the Intergovernmental Panel on Climate Change, edited by: Solomon, S., Qin, D., Manning, M., Chen, Z., Marquis, M., Averyt, K. B., Tignor, M., and Miller, H. L., Cambridge University Press, Cambridge UK, 996 pp., 2007.

Jones, D. A., Wang, W., and Fawcett, R.: High-quality spatial climate data-sets for Australia, Australian Meteorological and Oceanographic Journal, 58, 233-248, 2009.

Kleidon, A., Fraedrich, K., and Heimann, M.: A Green Planet Versus a Desert World: Estimating the Maximum Effect of Vegeta- tion on the Land Surface Climate, Climatic Change, 44, 471-493, doi:10.1023/a:1005559518889, 2000.

Kokic, P., Heaney, A., Pechey, L., Crimp, S., and Fisher, B. S.: Climate change, predicting the impacts on agriculture: a case study, Australian Commodities, 12, 161-170, 2005.

Köppen, W.: Das geographisca System der Klimate, in: Handbuch der Klimatologie, edited by: Köppen, W. and Geiger, G., Borntraeger, 1-44, 1936.

Köppen, W.: Die Wärmezonen der Erde, nach der Dauer der heissen, gemässigten und kalten Zeit und nach der Wirkung der Wärme auf die organische Welt betrachtet (The thermal zones of the earth according to the duration of hot, moderate and cold periods and to the impact of heat on the organic world), Meteorol. Z., 1, 215-226, 1884, translated and edited by: Volken, E. and Brönnimann, S., Meteorol. Z., 220, 2351-2360, 2011.

Kottek, M., Grieser, J., Beck, C., Rudolf, B., and Rubel, F.: World map of the Köppen-Geiger climate classification updated, Meteorol. Z., 15, 259-263, 2006.

Loehle, C.: Criteria for assessing climate change impacts on ecosystems, Ecology and Evolution, 1, 63-72, 2011.

Luo, Q., Bellotti, W., Williams, M., and Bryan, B.: Potential impact of climate change on wheat yield in South Australia, Agr. Forest Meteorol., 132, 273-285, 2005.

Markham, A.: Potential impacts of climate change on ecosystems: A review of implications for policymakers and conservation biologists, Clim. Res., 6, 179-191, doi:10.3354/cr006179, 1996.

Meehl, G. A., Covey, C., Delworth, T., Latif, M., McAvaney, B., Mitchell, J. F. B., Stouffer, R. J., and Taylor, K. E.: The WCRP CMIP3 multimodel dataset - A new era in climate change research, B. Am. Meteorol. Soc., 88, 1383-1394, doi:10.1175/BAMS-88-9-1383, 2007.

Mitchell, P. J. M., O'Grady, A. P., and Pinkard, E. A.: Defining past and future climate drivers of drought induced tree mortality: a case study from southern Australia, in preparation, 2012.

Mitchell, T. D.: Pattern scaling - An examination of the accuracy of the technique for describing future climates, Climatic Change, 60, 217-242, doi:10.1023/a:1026035305597, 2003.

Mpelasoka, F. S. and Chiew, F. H. S.: Influence of Rainfall Scenario Construction Methods on Runoff Projections, J. Hydrometeorol., 10, 1168-1183, 2009.

Nakicenovic, N. and Swart, R.: Special Report on Emission Scenarios, Intergovernmental Panel on Climate Change, 612 pp., 2000.

Peel, M. C., Finlayson, B. L., and McMahon, T. A.: Updated world map of the Köppen-Geiger climate classification, Hydrol. Earth Syst. Sci., 11, 1633-1644, doi:10.5194/hess-11-16332007, 2007.

Post, D. A., Chiew, F. H. S., Teng, J., Viney, N. R., Ling, F. L. N., Harrington, G., Crosbie, R. S., Graham, B., Marvanek, S., and McLoughlin, R.: A robust methodology for conducting largescale assessments of current and future water availability and use: A case study in Tasmania, Australia, J. Hydrol., 412-413, 233-245, doi:10.1016/j.jhydrol.2011.02.011, 2012.

Prentice, I. C., Cramer, W., Harrison, S. P., Leemans, R., Monserud, R. A., and Solomon, A. M.: A Global Biome Model Based on Plant Physiology and Dominance, Soil Properties and Climate, J Biogeogr., 19, 117-134, 1992.

Rubel, F. and Kottek, M.: Observed and projected climate shifts 1901-2100 depicted by world maps of the KoppenGeiger climate classification, Meteorol. Z., 19, 135-141, 
doi:10.1127/0941-2948/2010/0430, 2010.

Rubel, F. and Kottek, M.: Comments on: The thermal zones of the Earth by Wladimir Koppen (1884), Meteorol. Z., 20, 361-365, 2011.

Suppiah, R., Hennessy, K., Whetton, P. H., McInnes, K., Macadam, I., Bathols, J., Ricketts, J., and Page, C. M.: Australian climate change projections derived from simulations performed for the IPCC 4th Assessment Report, Aust. Meteorol. Mag., 56, 131$152,2007$.
Wang, E., Cresswell, H., Bryan, B., Glover, M., and King, D.: Modelling farming systems performance at catchment and regional scales to support natural resource management, NJAS-Wagen. J. Life Sc., 57, 101-108, 2009.

Zhang, L., Dawes, W. R., and Walker, G. R.: Response of Mean Annual Evapotranspiration to Vegetation changes at Catchment Scale, Water Resour. Res., 37, 701-708, 2001. 